\title{
SOCIAL AND ECONOMIC CONSEQUENCES OF BANKRUPCY OF THE COMPANIES IN UKRAINE
}

\author{
Olga Grybinenko \\ Department of Economic \\ Enterprise State Institution of Higher Education "National Mining University" \\ 19 D. Yavornitskogo ave., Dnipro, Ukraine, 49005 \\ hrybinenko.o.m@nmu.one
}

\begin{abstract}
As a result of the research it was determined that, the main causes of bankruptcy in the current economic conditions is a violation of financial stability; decline in business activity; significant debt; low liquidity assets, etc.; socio-economic consequences of bankruptcy is the fall in GDP, the decline in industrial and other products; reducing the supply of goods and services in the market; decline in innovation and capital investment; a negative multiplier effect and others; the main types of bankruptcy inherent in national enterprises - a fictitious bankruptcy; deliberate bankruptcy; technical failure; real bankruptcy. In recent years, fictitious bankruptcy is most typical for production assets of corporations that serves as cost centers; actual bankruptcy - in small and medium business; it had been found, that the overall socio-economic consequences of bankruptcy in Ukraine are negative; it has been found that, the nature of the relationship between bankruptcy and indicators of socio-economic development is fairly close, which suggests that domestic enterprises are essential curative measures, measures of financial rehabilitation of enterprises; simplification of the tax regime for small and medium businesses. The model of communication process of bankruptcy and socio-economic indicators of Ukraine demonstrated a significant correlation between the present bankruptcy and tax revenues to the state budget. The impact of bankruptcy on the overall economic development of the country is a scientific and reasonable, which makes recommendations for further research.

I have proved the important meaning of bankruptcy in the treatment of various scientists. There were presented internal and external causes of bankruptcy and its types. The next things were developed: the clarification of the external and internal in relation to the subject of business factors affecting its activities; the order of the enterprise is declared bankrupt; the main socio-economic consequences of the bankruptcy of enterprises in Ukraine.

The research results can be used in the planning of government measures to prevent the bankruptcy of enterprises and developing strategies to improve the socio-economic development. In future we plan to continue the study and to determine the nature of the model applied to the process of bankruptcy and socio-economic indicators of Ukraine.
\end{abstract}

Keywords: bankruptcy, bankrupt businesses, the consequences of bankruptcy, indicators of social and economic development.

\section{Introduction}

Today, bankruptcy shall be recognized as a common phenomenon. Bankruptcy is the realization of the company's catastrophic risks in the course of its business, resulting in failure to meet time-bound claims of creditors and fulfill budget liabilities. The main causes of this phenomenon are the following: significant noncompliance with financial soundness of companies in case of excess of liabilities over assets; prolonged insolvency of the company; low liquidity of assets; significant imbalance of positive and negative cash flows and others. Bankruptcy in the market economy serves as a regulator "rejecting" unprofitable, inefficient and insolvent businesses. Nevertheless, bankruptcy causes a number of negative socio-economic consequences, spread of unemployment in the country being the most important of them. The growing number of liquidated and bankrupt companies in Ukraine encourages finding ways to address this issue at the national level, in turn creating the need to study the main problems and causes for bankruptcy of Ukrainian companies. So, the issue of bankruptcy of businesses in Ukraine is undoubtedly topical.

\section{Review of recent studies and publications}

Topicality of the problem of bankruptcy in Ukraine is aggravated due to the crisis in the economy. The results of theoretical analysis of present scientific achievements in the field of bankruptcy have shown that modern scientists consider bankruptcy as one of the issues of theory and practice of anti-crisis management. Besides, they specify the nature and reasons of bankruptcy and 
improve the mechanism of state regulation of the financial recovery of debtors and elimination of bankrupt $[1,2]$. The results of their proposals and improvements have been introduced in the process of development of bankruptcy regulations. The similarities and differences in the bankruptcy laws of Western and former Soviet countries have been analysed in numerous sources. Some researchers [3-5] outline the problems of adaptation of national legislation in the context of European integration. The numerous researches deal with this problem, but due to European standards in economic terms, the issues of adaptation of domestic bankruptcy procedures have not been studied completely, causing its topicality and necessity of in-depth investigation [6, 7]. However, the analysis of system consequences of the bankruptcy effects on the social and economic situation in the country, changes in gross production and markets are not sufficiently studied by scientists.

\section{The aim and objectives of research}

The objective of the research paper is the analysis of the socio-economic consequences of bankruptcy of domestic companies in the present conditions.

To achieve this aim it is necessary to solve the following objectives:

- to analyse the causes, criteria and factors of bankruptcy in the current economic conditions of domestic enterprises;

- to identify and give appropriate characteristics to different types of bankruptcy arising from business activities in the current business environment;

- to define results and socio-economic consequences of bankruptcy in Ukraine;

- to determine the level of link of bankruptcy process and socio-economic indicators of Ukraine;

- to develop a link model of bankruptcy process and socio-economic indicators of Ukraine.

\section{Materials and Methods}

Research methodology of the negative socio-economic impact of bankruptcy of the companies in Ukraine includes the following methods: systematization and synthesis regarding generalization of causes and consequences of bankruptcy, procedure for announcing the company bankrupt; system approach, synthesis, induction and deduction - to identify negative social and economic consequences of bankruptcy for the economy of the state and to form a system of indicators evaluating these negative effects; statistical analysis - to study the state of bankruptcy of the companies in Ukraine and socio-economic processes in Ukraine; correlation and regression analysis - to study the impact level of bankruptcy of the companies in Ukraine on socio-economic processes.

\section{Result of the research}

Unstable economic and political environment in the country, inadequate legal and tax regulations have increased the number of insolvent companies which go bankrupt, leading in many cases to liquidation of such companies. Bankruptcy issues are particularly topical in times of financial instability. The subject of bankruptcy is a debtor which failure to cover its financial liabilities is established by the commercial court. Individual structural units of the legal entity (branches, representative offices, etc.) cannot be the subjects of bankruptcy $[4,8]$. In analyzing the process of bankruptcy of the companies it is important to understand the causes and consequences of bankruptcy (Fig. 1).

There are also internal and external factors with respect to the business entity affecting its activities. External factors are the most dangerous due to the fact that the possibility of impact on them is minimal, and the consequences of their realization can be devastating [9]. The main ones include:

1) economic (inflation rates, tax rates and bank loans rates, exchange rates, income levels, etc.);

2) political - are caused by the actions and intentions of the central and local governments, their attitude to different sectors, regions of a country and forms of ownership, various groups of influence in public authorities and business administration;

3) market (trends in demographic situation, life cycles of products, competition, etc.);

4) technology - resulting from the impact of technological progress on the economy; 
5) social and cultural - those covering such phenomena and processes as the customs and traditions, attitude to work dominant in a society, welfare, public education, attitude to private business and the possibility of independent entrepreneurial activity;

6) International - related to the globalization of the economy, activity of multinational companies, economic and military-political associations [10].

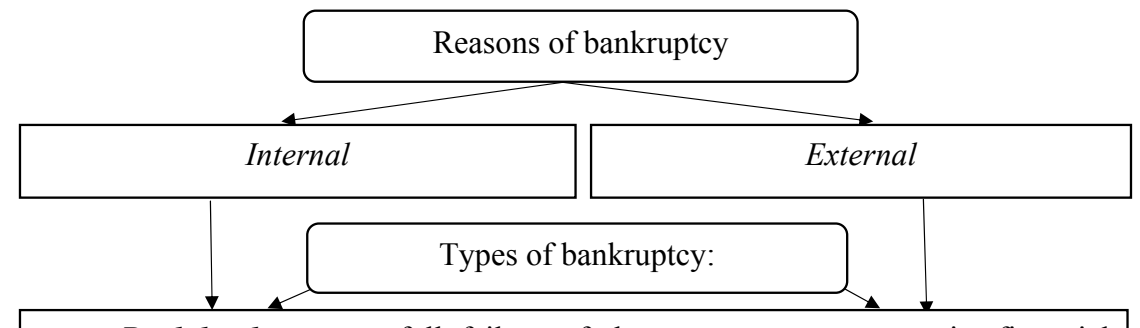

Real bankruptcy - full failure of the company to resume its financial stability and solvency because of the actual loss of capital. The company is legally declared bankrupt.

Technical bankruptcy - bankruptcy caused by a considerable past-due accounts receivable and exceeding of these accounts receivable over accounts payable, and the amount of assets considerable exceeds financial liabilities. The company is not legally declared bankrupt, efficient anti-crisis management is provided.

Deliberate bankruptcy - intentional creation of increase of insolvency by the manager or the owner of the company, causing economic damage to personal interests of other persons, deliberately incompetent financial management. All elicited facts are prosecuted bv criminal law.

Fictitious bankruptcy - deliberately untruthful declaration by the company of its insolvency for the purpose of deceiving the creditors to get an extension for fulfilling its liabilities or discounts on the amounts payable. All elicited facts are prosecuted by criminal law.

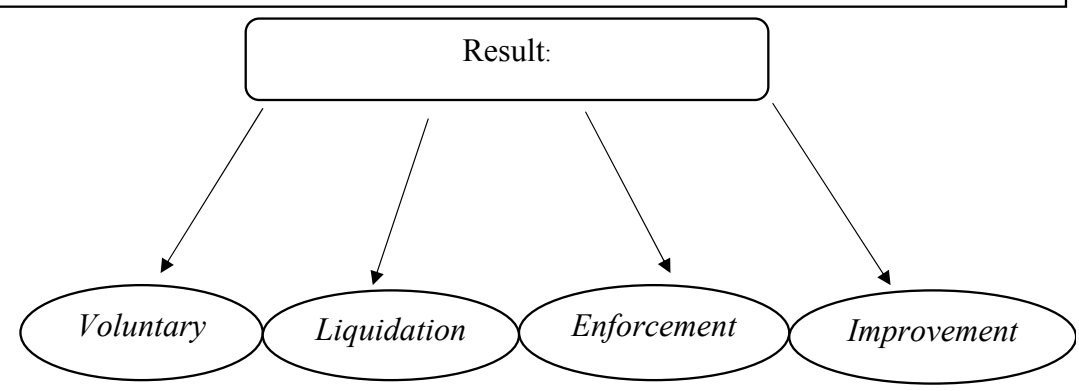

Fig. 1. Causes and results of bankruptcy of a company Note: composed by the author

The procedure of declaring the company bankrupt is the following:

1) the procedure of establishing the fact of the debtor's insolvency and the creditor's claims cogency (if it/he is the initiator of filing a suit);

2) identification of all creditors and potential insolvency turnarounds;

3) readjustment (if possible) or drafting a settlement agreement;

4) finding a debtor bankrupt;

5) the procedure for satisfying the creditors' claims by liquidation of the debtor's property assets [11].

The consequences of finding the company bankrupt are the following:

1) termination of business activities;

2) transition of the title in the bankrupt's property of its/his property rights and responsibilities to the liquidation committee; 
3) all the bankrupt's debts are deemed due;

4) accrual of penalties and interest on all types of debt is terminated;

5) transaction to sell the property may be deemed invalid three months before the date of application for bankruptcy and up to a year, before initiation of a case on the sale of property or taking liabilities that led the company to the state of crisis;

6) funds raised by a liquidation committee from the sale of the bankrupt's property are transferred to satisfy creditors' claims [12].

As to the consequences of bankruptcy, they are unfortunately disappointing, but that is due because our legislation is aimed not at overcoming the crisis but at the liquidation of the company [7]. The consequences of bankruptcy for businesses of Ukraine are considered in terms of the following key trends (Table 1).

\section{Table 1}

Socio-economic consequences of bankruptcy in Ukraine

\begin{tabular}{cc}
\hline Item No. & Consequences of bankruptcy \\
1 & Decline in GDP. Decline in the production volume of industrial and other products causing a GDP decline \\
3 & Decreased supply of goods and services in the market causing the increase in imports. \\
4 & Reduced tax revenues from companies (income tax, excise tax, etc.) \\
5 & Reduced funding social and cultural spheres due to reduction in tax revenues. \\
7 & Reduced jobs causing increase in the unemployment rate \\
& Formation of a negative multiplier effect
\end{tabular}

Note: composed by the author

Reduced number of businesses primarily causes: decline in total production volume which adversely affects the GDP of the country as a whole and GDP per capita particular, in addition commodity supply in the market declines significantly reducing commodity segments and can lead to increased dependence on imports. Drop in capital investment in terms of accumulative values and partial drop in the rankings of making business in the country are obvious. Technically, the decrease in the production volumes of a company may affect tax deductions to the state budget and therefore adversely affect budget expenditures. In addition, the situation in the labour market become aggravated and drop in purchasing power may be observed. All these trends lead to overall adverse socio-economic multiplier effect.

Accordingly, let us present trends in key indicators of socio-economic development of Ukraine for the period from 2010 to 2016 that can characterize improvement or worsening of socio-economic situation. In our opinion, the most important of them include: Real GDP per Capita, Industrial Production Growth Rate, Industrial Production Sales Volume, Tax Revenues and State Budget Expenditures, Unemployment Rate (Table 2).

The deviations show that the values of Real GDP (in USD) per Capita and Industrial Production Growth Rates declined, that should be interpreted negatively. Nevertheless, Unemployment Rate declined. Rather, these results are associated with the establishment of many new businesses that are still at the early stages of their life cycle. Let us examine the dynamics of bankruptcy and liquidation of Ukrainian companies from 2010 to 2016 (Table 3).

It should be noted that the number of businesses during a certain period of time substantially reduced, while the number of bankrupt companies increased, though slightly. The largest number of bankrupt companies is registered in 2011 and 2014. Attention should also be paid to the share of businesses that were unprofitable, because due to systematic loss they are subjected to risks and will be found bankrupt in future. 
Table 2

The main indicators of economic and social development of Ukraine

\begin{tabular}{|c|c|c|c|c|c|c|c|c|}
\hline Years & 2010 & 2011 & 2012 & 2013 & 2014 & 2015 & 2016 & $\begin{array}{l}\text { Deviation } \\
(2016-2010)\end{array}$ \\
\hline $\begin{array}{l}\text { Real GDP (in USD) } \\
\text { per capita }\end{array}$ & 2974.0 & 3570.8 & 3856.8 & 4030.3 & 3014.6 & 2115.4 & 2234.4 & -7039.0 \\
\hline $\begin{array}{c}\text { Industrial Production } \\
\text { Growth Rate, } \%\end{array}$ & 119.7 & 104.9 & 123.2 & 102.0 & 111.9 & 119.9 & 101.2 & -18.5 \\
\hline $\begin{array}{l}\text { Industrial Production } \\
\text { Sales Volumes, } \\
\text { mln. UAH }\end{array}$ & 402.9 & 1365.6 & 1939.1 & 2242.6 & 2530.3 & 2597.2 & 3536.3 & 3133.4 \\
\hline $\begin{array}{c}\text { Tax Revenues to } \\
\text { the State Budget, } \\
\text { mln. UAH }\end{array}$ & 179.5 & 261.6 & 274.7 & 262.7 & 280.2 & 409.4 & 502.6 & 323.1 \\
\hline $\begin{array}{l}\text { State Budget } \\
\text { Expenditures, } \\
\text { mln. UAH }\end{array}$ & 225.8 & 238.6 & 271.2 & 287.6 & 299.6 & 402.9 & 511.6 & 285.8 \\
\hline $\begin{array}{l}\text { Unemployment Rate } \\
\text { in } \% \text { to the working age } \\
\text { population }\end{array}$ & 20.1 & 23.9 & 19.5 & 21.4 & 19.7 & 20.9 & 18.2 & -1.9 \\
\hline
\end{tabular}

Source: [8, 13]

Table 3

The dynamics of bankruptcy and liquidation of Ukrainian companies from 2010 to 2016

\begin{tabular}{|c|c|c|c|c|c|c|c|c|}
\hline Years & 2010 & 2011 & 2012 & 2013 & 2014 & 2015 & 2016 & $\begin{array}{c}\text { Deviation } \\
(2016-2010)\end{array}$ \\
\hline $\begin{array}{c}\text { Number of } \\
\text { business entities, units }\end{array}$ & 378,810 & 375,695 & 364,935 & 393,327 & 341,001 & 343,440 & 343,477 & $-35,333$ \\
\hline $\begin{array}{l}\text { Number of bankrupt } \\
\text { business entities, units }\end{array}$ & 2,888 & 3,488 & 2,891 & 2,655 & 3,488 & 3,399 & 3,409 & -521 \\
\hline $\begin{array}{l}\text { Share of bankrupts out } \\
\text { of the total number, } \%\end{array}$ & 0.8 & 0.9 & 0.8 & 0.7 & 1.0 & 0.9 & 1.0 & -0.7 \\
\hline Companies at a loss, $\%$ & 46.3 & 42.6 & 37.0 & 35.0 & 34.5 & 26.7 & 33.3 & -13.0 \\
\hline
\end{tabular}

Source: [13]

\section{1. Research findings}

As one can see, socio-economic consequences of bankruptcy of the companies in Ukraine are negative. Reduced number of businesses causes a reduction in production, which in turn causes the decline in gross domestic product, increased unemployment rate that requires additional payments, reduced tax revenues, etc.

Therefore, it is useful to mention the main problems of bankruptcy of Ukrainian companies: imperfect legislative framework for regulating bankruptcy issues, which, despite reforms, requires revision; lack of any public statistical and analytical data on the dynamics of bankruptcy in Ukraine (excluding paid sources) to assess the real scale of the phenomenon and understand the urgency of solving the problem; insufficient government control over bankruptcy of the companies in Ukraine and implementation of measures to reduce it; lack of methodology for determining and preventing bankruptcy of companies by the types of economic activity; lack of government support to insolvent private companies; lack of counseling centers to help insolvent companies; lack of funds and qualified professionals to create separate divisions for crisis management in the company [7]. 
Based on the above data we would graphically represent relation of unprofitable and bankrupt companies (Fig. 2).

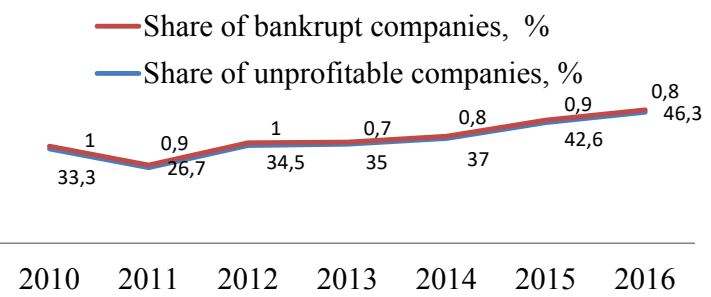

Fig. 2. Relation of unprofitable and bankrupt companies Source: $[8,13]$

As we see, the close relation is observed in 2011 and 2014. The largest number of companies declared bankrupt was recorded in these years. To determine the effect of bankrupt companies on the economic and social development of Ukraine the correlation analysis is carried out. Correlation factor (r) is calculated by the formula 1 :

$$
r_{x y}=\sum d_{x}+d_{y} \sqrt{\sum d_{x}^{2}+d_{y}^{2}}
$$

The calculated factors are formed in Table 4. When interpreting the results of correlation analysis, the error is $\mathrm{p}>0,70$.

Table 4

Closeness of relation of the bankruptcy process and indicators of socio-economic development of Ukraine

\begin{tabular}{|c|c|c|c|c|c|c|}
\hline Indicators & $\begin{array}{l}\text { Real GDP } \\
\text { (in USD) } \\
\text { per capita }\end{array}$ & $\begin{array}{c}\text { Industrial } \\
\text { Production } \\
\text { Growth Rates, \% }\end{array}$ & $\begin{array}{l}\text { Industrial Produc- } \\
\text { tion Sales Vol- } \\
\text { umes, mln. UAH }\end{array}$ & $\begin{array}{c}\text { Tax Revenues } \\
\text { to the State Budget, } \\
\text { mln. UAH }\end{array}$ & $\begin{array}{c}\text { State Budget } \\
\text { Expenditures, } \\
\text { mln. UAH }\end{array}$ & $\begin{array}{l}\text { Unemployment level } \\
\text { in \% to the working } \\
\text { age population }\end{array}$ \\
\hline $\mathrm{m}^{*} \sigma_{\mathrm{x}}$ & 1843.788 & 22.393 & 2441.8 & 265.943 & 250.755 & 4 \\
\hline $\mathrm{m}^{*} \sigma_{\mathrm{y}}$ & 856.906 & 856.906 & 856.906 & 856.906 & 856.906 & 856.906 \\
\hline $\begin{array}{l}\text { Pearson } \\
\text { Correlation } \\
r_{x y}\end{array}$ & 0.611 & 0.196 & 0.388 & 0.505 & 0.415 & 0.023 \\
\hline
\end{tabular}

Note: composed by the author

As one can see, there is always relation of the process of bankruptcy with indicators of socio-economic development of Ukraine, the indicator of GDP $(r=0.611$ with $\mathrm{p}<0.05)$ and the indicator of GDP tax revenues $(\mathrm{r}=0.505$ with $\mathrm{p}<0.05)$ are particularly exposed. This is schematically shown in Fig. 3.

Relation of the bankruptcy process with industrial production growth rate and unemployment rate is slight, but still exists. Moderate relation is observed with the indicators of industrial products sold and expenditures of the state budget. There is a significant relation between bankruptcy and tax revenues to the state budget. And the rate of Real GDP per Capita is adversely affected by the process of bankruptcy of the companies in Ukraine to the largest extent that should be interpreted negatively. Thus, the effect of bankruptcy on the overall economic development of the country is scientifically justified. 


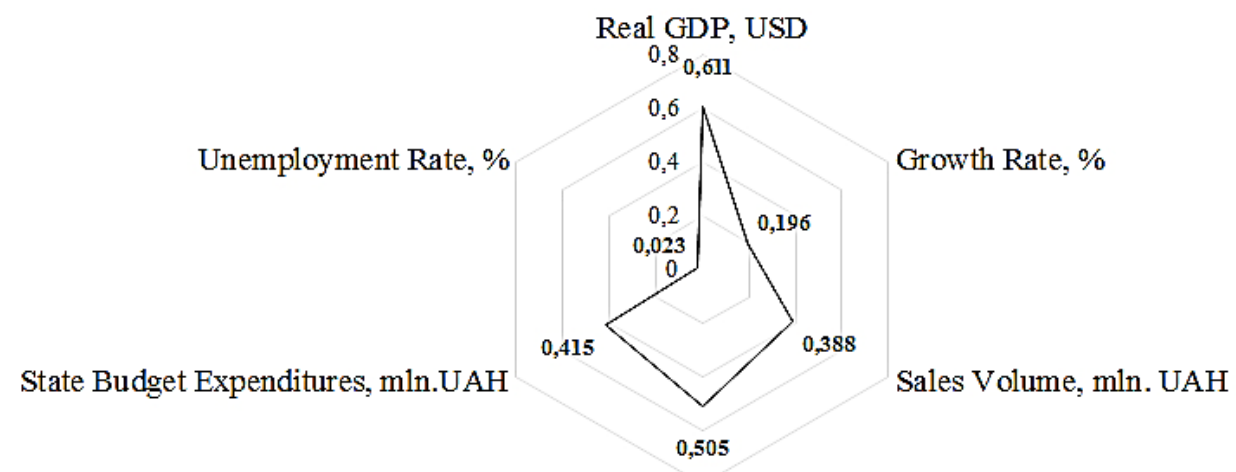

Tax Revenues, mln.UAH

Fig. 3. Relation of bankruptcy process and indicators of socio-economic development of Ukraine Note: composed by the author

\section{Discussion of the results}

In research, the following methods have been used: theoretical generalization, systematization, correlation analysis, modelling that are reliable and have significant benefits. They helped to prove that growing number of bankrupt enterprises has a significant impact on the deterioration of the socio-economic development of a country in general, and conversely, the complications of conditions of small and medium businesses by the state, increase of the minimum wage trigger the process of closing or elimination of the business, i. e. it stimulate bankruptcy processes for entrepreneurs. The results of the research may be used in the planning of government measures to prevent the bankruptcy of enterprises and developing strategies for improvement of the socio-economic development of a country. In future, we plan to continue the study and to determine the applied nature of the developed link model of bankruptcy process and socio-economic indicators of Ukraine.

\section{Conclusions and recommendations for further research}

During investigation, the following results have been determined:

The main causes of bankruptcy in the current economic conditions is a violation of financial stability; decline in business activity; significant debt; low liquid assets, etc.;

Socio-economic consequences of bankruptcy is the fall in GDP, decline in industrial and other products; reduction of the supply of goods and services in the market; decline in innovation and capital investment; formation of negative multiplier effect and others. The overall socioeconomic consequences of bankruptcy Ukraine have been found out to be negative;

The main types of bankruptcy inherent for national enterprises are fictitious bankruptcy; deliberate bankruptcy; technical failure; real bankruptcy. In recent years, fictitious bankruptcy is the most typical for production assets of corporations that serve as cost centres; actual bankruptcy is observed in small and medium businesses;

The relationship between bankruptcy and indicators of socio-economic development has been found out to have close nature. It shows that domestic enterprises are in necessity of curative measures, measures of financial rehabilitation of enterprises; simplification of the tax regime for small and medium businesses.

The developed link model of bankruptcy process and socio-economic indicators of Ukraine has demonstrated a significant correlation between the present bankruptcy and tax revenues to the state budget.

The impact of bankruptcy on the overall economic development of the country is scientifically justified giving the ground for further research. 


\section{References}

[1] Blank, I. A. (2005). Financial risk management. Kyiv: Nika-Centre, 600.

[2] Volosovych, S. V. (2013). Credit insurance risk areas. Kyiv: KNTEU, 388.

[3] Blank, I. A. (1999). Financial management: a training course. Kyiv: Nika-Centre, 528.

[4] Bratyshchenko, Yu. (2002). Grounds for Bankruptcy. Economics. Finance. Law, 1, 85.

[5] Kravtsova, O. M. (2013). Bankruptcy in terms of adaptation to EU: Economic Aspect. Economic Annals-XXI, 3-4 (2), 26-28.

[6] Stepanov, O. (2004). Problem Issues of Declaring Debtor's Transactions Invalid in the Bankruptcy (Insolvency) Procedure. Law of Ukraine, 12, 85-96.

[7] Trots, I. (2014). Statistical Review of Bankruptcy of Ukrainian Companies: National and Regional Aspects. Journal of Social and Economic Research, 3, 170-178. Available at: http://nbuv.gov.ua/UJRN/ Vsed_2014_3_28

[8] State Statistics Service of Ukraine (2017). Available at: http://www.ukrstat.gov.ua

[9] Issues of the Modern Science and Education (2011). Institute of Scientific Forecasting, the Crimean Institute of Economics and Commercial Law, The Povolzhzhie Academy of State Service, TK Meganom, Kyiv, 82.

[10] Kovalenko, O., Skliarenko, O. (2013). Bankruptcy of the Companies of Ukraine: Reasons and Consequences. Available at: http://www.zgia.zp.ua/gazeta/evzdia_4_066.pdf

[11] On Recovery of the Debtor's Solvency or Declaring It/Him Bankrupt (2011). Verkhovna Rada of Ukraine, No. 4212-VI. Available at: http://zakon4.rada.gov.ua/laws/show/4212-17

[12] Brin, P. V., Bondarenko, A. Yu. (2013). Analysis of the Modern Condition of the Bankruptcy Institute in Ukraine. Visnyk NTU «KhPI», 69 (1042), 155-161.

[13] Analytical Information of the Integrated System of Information and Legal Support. Liga: Zakon ENTERPRISE. 9.1.5. Available at: http://products.ligazakon.ua/systems/enterprises 